\title{
KERAGAAN MUTU BIJI KAKAO KERING DAN PRODUK SETENGAH JADI COKELAT PADA BERBAGAI TINGKATAN FERMENTASI
}

\author{
Dian Adi A. Elisabeth \\ Balai Pengkajian Teknologi Pertanian (BPTP) Bali \\ L. E. Setijorini (vica@mail.ut.ac.id) \\ Universitas Terbuka
}

\begin{abstract}
Basic of cocoa bean preparation process is fermentation. Fermentation is done especially to improve and build specific chocolate flavour of cocoa bean and its products, i. e. cocoa liquor, butter, and powder; and also to decrease the disliked flavors, like bitter and acid. Research of cocoa bean fermentation was hold on in Subak Abian Pucaksari, Tabanan. This research involved 20 cooperative farmers with 0,5 hectare farm area per each farmer. The treatment used was time of cocoa bean fermentation, i.e. without fermentation, not fully fermentation (4 days), and fully fermentation (5 days). Variables observed were dried cocoa bean's physic and chemical quality, and also cocoa product's chemical and organoleptic quality. Organoleptic test done to cocoa liquor and powder was descriptive and ranking test used 15 semi-trained panelists. The result showed that the fermentation process had significant influence to dried cocoa bean's chemical quality and its products. Fermentation had no significant influence to dried cocoa bean's physic quality. For organoleptic quality attributes, all panelists gave the highest rank for cocoa liquor and powder prepared from fully fermented cocoa bean.
\end{abstract}

Keywords : cacao bean, cocoa product, fermentation, quality

Perkembangan kakao di Provinsi Bali cukup pesat dan kakao menjadi salah satu komoditas perkebunan utama yang diandalkan. Pemprov Bali (2004) menyebutkan luas areal penanaman kakao di Bali pada tahun 2000 mencapai 6.564 ha dengan produksi 4.424 .367 ton dan berkembang menjadi 8.764 ha pada tahun 2004 dengan produksi mencapai 6.123 .869 ton; dan terutama berada di Kabupaten Jembrana dan Tabanan. Hampir keseluruhan areal perkebunan kakao ini adalah perkebunan rakyat.

Namun perkembangan produksi kakao di Indonesia, termasuk di Provinsi Bali seringkali tidak diikuti dengan perbaikan mutu biji kakao. Biji kakao yang berasal dari perkebunan rakyat cenderung bermutu rendah. Yusianto (1994) menyebutkan bahwa rendahnya mutu biji kakao ini terutama disebabkan oleh cara pengolahan yang kurang baik, seperti biji kakao yang tidak difermentasi atau proses fermentasi yang kurang sempurna. Oleh karena itu, untuk meningkatkan nilai tambah kakao sekaligus meningkatkan pendapatan petani kakao di Bali, dilakukan beberapa strategi penelitian pasca panen. Tahap pertama adalah penelitian untuk menyiapkan sarana dan teknologi pengolahan produk primer secara kolektif (kelompok) sehingga dihasilkan peningkatan mutu biji kakao; dan tahap kedua adalah penelitian lanjutan untuk mengembangkan produk sekunder 
kakao sehingga dapat memberikan nilai tambah lebih besar bagi petani. Produk olahan dari biji kakao yang bisa dihasilkan antara lain pasta, lemak, dan bubuk cokelat. Produk ini banyak dimanfaatkan sebagai bahan baku pada industri makanan, farmasi, dan kosmetika.

Fermentasi merupakan inti dari proses pengolahan biji kakao. Fermentasi tidak hanya bertujuan untuk membebaskan biji dari pulp dan mencegah pertumbuhan biji, namun terutama juga untuk memperbaiki dan membentuk citarasa cokelat yang khas (enak dan menyenangkan) serta mengurangi rasa sepat dan pahit pada biji (Widyotomo, Mulato, \& Handaka, 2004). Misnawi (2005) menyatakan bahwa fermentasi merupakan tahapan pengolahan yang sangat vital untuk menjamin dihasilkannya citarasa cokelat yang baik. Praktek fermentasi yang salah dapat menyebabkan kerusakan citarasa yang tidak dapat diperbaiki melalui modifikasi pengolahan selanjutnya.

Citarasa biji kakao dan produk olahannya ditentukan oleh fermentasi yang sempurna, buah yang masak dan sehat serta pengeringan yang baik. Fermentasi sempurna yang dimaksud adalah fermentasi selama 5 hari sesuai dengan penelitian Sime-Cadbury (Atmawinata, Mulato, Widyotomo, \& Yusianto, 1998). Jika fermentasi yang dilakukan kurang atau tidak sempurna, selain citarasa khas cokelat tidak terbentuk, juga seringkali dihasilkan citarasa ikutan yang tidak dikehendaki, seperti rasa masam, pahit, kelat, sangit, dan rasa tanah (Atmawinata et al., 1998). Selama ini, fermentasi sempurna, yaitu selama 5 hari baru dilaksanakan oleh sebagian kecil petani di lapangan, sementara sebagian besar lainnya masih belum melaksanakan proses fermentasi pada produksi biji kakaonya atau melakukan fermentasi yang tidak tepat/sempurna.

Menurut Mulato, Widyotomo, \& Handaka, (2002) dari Puslit Kopi dan Kakao, spesifikasi mutu biji kakao kering yang sesuai untuk digunakan sebagai bahan baku makanan cokelat adalah sebagai berikut: tingkat fermentasi biji adalah 5 hari (fermentasi sempurna), kadar air 7\%, kadar kulit ari 12$13 \%$, kadar lemak 50-51\%, biji memiliki ukuran yang seragam, dengan kadar kotoran, baik untuk jamur, benda asing lunak, maupun benda asing keras adalah nol atau nihil.

Fermentasi dapat dilakukan dengan beberapa metode, seperti fermentasi tumpukan, fermentasi dalam keranjang, dan fermentasi dalam kotak. Pemilihan metode fermentasi tergantung pada kemudahan penerapan, kemudahan memperoleh wadah fermentasi, serta ketersediaan tenaga kerja.

Pasta cokelat atau cocoa liquor dibuat dari biji kakao kering melalui beberapa tahapan proses sehingga biji kakao yang semula padat menjadi bentuk cair atau semicair. Pasta cokelat dapat diproses lebih lanjut menjadi lemak dan bubuk cokelat. Mula-mula, pecahan nib hasil penyangraian dilumatkan (dihaluskan) dengan menggunakan mesin pelumat tipe silinder atau pemasta kasar menghasilkan pasta kasar; yang kemudian dapat diikuti dengan pelumatan lanjut menggunakan silider berputar atau refiner sampai diperoleh pasta cokelat dengan kehalusan tertentu.

Lemak cokelat atau cocoa butter merupakan lemak nabati alami yang mempunyai sifat unik, yaitu tetap cair pada suhu di bawah titik bekunya; sehingga pabrik makanan cokelat perlu menggunakan teknik tempering khusus untuk mengubah struktur kristal lemak cokelat sedemikian rupa agar lemak tetap padat meskipun sudah mencapai titik lelehnya, yaitu $34-35^{\circ} \mathrm{C}$. Lemak cokelat mempunyai warna putih kekuningan dan berbau khas cokelat (Mulato et al., 2002). Lemak cokelat dikeluarkan dari pasta cokelat dengan cara dikempa atau dipres. Mula-mula, pasta kakao dimasukkan ke dalam alat kempa hidrolis yang memiliki dinding silinder yang diberi lubang-lubang sebagai penyaring. Cairan lemak akan keluar melewati lubang-lubang tersebut, sedangkan bungkil cokelat sebagai hasil sampingnya akan tertahan di dalam silinder. 
Bubuk cokelat atau cocoa powder diperoleh melalui proses penghalusan bungkil (cocoa cake) hasil pengempaan. Untuk memperoleh ukuran yang seragam, setelah penghalusan perlu dilakukan pengayakan. Bubuk cokelat relatif sulit dihaluskan dibandingkan bubuk/tepung dari bijibijian lain karena adanya kandungan lemak. Lemak yang tersisa di dalam bubuk mudah meleleh akibat panas gesekan pada saat dihaluskan sehingga menyebabkan komponen alat penghalus bekerja tidak optimal. Pada suhu yang lebih rendah dari $34^{\circ} \mathrm{C}$, lemak menjadi tidak stabil menyebabkan bubuk mudah menggumpal dan membentuk bongkahan (lump) (Mulato et al., 2002).

Penelitian dilakukan dengan tujuan untuk melihat pengaruh lama fermentasi biji kakao terhadap keragaan mutu fisik dan kimia biji kakao, serta keragaan mutu kimia dan organoleptik produk setengah jadi, meliputi pasta, lemak, dan bubuk cokelat yang dibuat dari biji kakao tersebut.

\section{METODOLOGI}

Penelitian dilaksanakan di Subak Abian Pucaksari, Desa Mundeh Kauh, Kecamatan Selemadeg Barat, Kebupaten Tabanan pada bulan Juli sampai Oktober 2006 dengan melibatkan 20 orang petani kooperator, masing-masing dengan luasan lahan 0,5 hektar.

Perlakuan yang digunakan dalam penelitian adalah lama fermentasi biji kakao, yang terdiri dari 3 tingkatan, yaitu tanpa fermentasi, fermentasi tidak sempurna (4 hari), dan fermentasi sempurna (5 hari) dengan menggunakan bak-bak fermentasi. Pengeringan dilakukan dengan cara penjemuran selama 6-7 hari dalam keadaan matahari bersinar penuh (cuaca cerah). Biji kakao kering yang diperoleh kemudian diolah lebih lanjut menjadi produk setengah jadi cokelat, yaitu pasta, lemak, dan bubuk cokelat.

Variabel yang diamati adalah keragaan mutu fisik biji kakao kering, meliputi : bobot biji kering per buah, jumlah biji kering per buah, jumlah biji kering per 100 gram, bobot per biji kering, kelompok mutu biji, kadar nib, kadar kulit ari, dan nilai buah (pod value); serta mutu kimia biji kakao kering, meliputi : kadar lemak, kadar air, pH, total asam, dan kadar gula pereduksi. Untuk produk setengah jadi cokelat, variabel mutu yang diamati adalah mutu kimia, meliputi : kadar air, kadar lemak, kadar protein, kadar karbohidrat, dan kadar abu; serta pH untuk bubuk cokelat. Hasil analisis mutu fisik dan kimia yang didapat kemudian dianalisis menggunakan analisis sidik ragam, dilanjutkan dengan uji Duncan jika hasil berbeda nyata.

Selain itu, dilakukan juga uji organoleptik terhadap produk pasta dan bubuk cokelat, meliputi uji deskriptif dan uji rangking untuk mendapatkan deskripsi panelis mengenai atribut mutu organoleptik produk (seperti warna, aroma, tekstur, dan rasa pahit/bitterness) serta untuk menunjukkan rangking/urutan tingkat penerimaan panelis terhadap produk dengan menggunakan 15 orang panelis semi terlatih sebagai ulangan. Semua analisis dilakukan di Laboratorium Analisis Hasil Pertanian, Fakultas Teknologi Pertanian, Universitas Udayana.

\section{HASIL DAN PEMBAHASAN}

\section{Biji Kakao Kering}

Mutu biji kakao sangat dipengaruhi oleh beberapa faktor pra panen, seperti sifat genetis tanaman, lingkungan fisik, dan praktek budidaya, serta penanganan pasca panen seperti pemanenan, fermentasi, pencucian, pengeringan, dan pengangkutan (Putra \& Wartini, 1998). Sifat genetis tanaman tidak hanya menentukan citarasa, tetapi juga kadar lemak, kadar kulit, dan berat biji. 
Tabel 1 menunjukkan keragaan fisik biji kakao kering yang menjadi bahan baku pengolahan produk setengah jadi cokelat.

Tabel 1. Keragaan Fisik Biji Kakao Kering

\begin{tabular}{lccc}
\hline \multicolumn{1}{c}{ Parameter/Biji kering } & Non Fermentasi & $\begin{array}{c}\text { Fermentasi } \\
\text { Tidak Sempurna }\end{array}$ & $\begin{array}{c}\text { Fermentasi } \\
\text { Sempurna }\end{array}$ \\
\hline Bobot biji kering/buah (g) & $50,50 \mathrm{a}$ & $47,90 \mathrm{a}$ & $42,90 \mathrm{a}$ \\
Jumlah biji kering per buah & $41,50 \mathrm{~b}$ & $32,90 \mathrm{a}$ & $31,10 \mathrm{a}$ \\
Jumlah biji kering per 100 gram & $88,79 \mathrm{a}$ & $68,61 \mathrm{a}$ & $73,98 \mathrm{a}$ \\
Bobot per biji kering (g) & $1,22 \mathrm{a}$ & $1,46 \mathrm{a}$ & $1,38 \mathrm{a}$ \\
Kelompok mutu biji & Mutu A & Mutu A & Mutu A \\
Kadar nib (\%) & $84,90 \mathrm{a}$ & $86,60 \mathrm{a}$ & $87,90 \mathrm{a}$ \\
Kadar kulit ari (\%) & $15,10 \mathrm{a}$ & $13,40 \mathrm{a}$ & $12,10 \mathrm{a}$ \\
Nilai buah (pod value) & $21,33 \mathrm{a}$ & $21,35 \mathrm{a}$ & $23,86 \mathrm{a}$ \\
\hline
\end{tabular}

Keterangan : Angka yang diikuti huruf yang sama pada lajur yang sama tidak berbeda nyata pada uji sidik ragam $(a=0,05)$

Ada 3 golongan mutu biji kakao yang dijadikan standar dalam perdagangan, yaitu mutu $A, B$, dan C. Mutu A adalah golongan biji dengan ukuran besar dan jumlah biji 85-90 per 100 gram. Mutu $B$ adalah golongan biji dengan ukuran medium dan jumlah biji 95-110 per 100 gram. Sementara, mutu C adalah golongan biji dengan ukuran kecil dan jumlah biji di atas 120 per 100 gram (Mulato et al., 2002). Setiap buah kakao umumnya dapat berisi sekitar 30-40 biji (Putra \& Wartini, 1998).

Tabel 1 menunjukkan bahwa secara umum, keragaan mutu fisik dari ketiga biji kakao kering yang dihasilkan adalah baik, dimana jumlah biji kakao kering per buah berkisar 31-42 biji dengan bobot per biji kering berkisar 1,22-1,46 gram dan termasuk dalam kelompok biji dengan Mutu $A$. Hasil analisis sidik ragam menunjukkan bahwa perlakuan tingkat fermentasi tidak berpengaruh nyata pada bobot biji kering per buah, jumlah biji kering per 100 gram, dan bobot per biji kering.

Fermentasi berpengaruh terhadap kadar kulit ari biji kakao. Selama proses fermentasi terjadi penguraian pulp. Semakin lama fermentasi, proses penguraian akan semakin sempurna sehingga sisa pulp yang masih menempel pada kulit akan semakin sedikit. Kadar kulit ari yang tinggi berpengaruh pada rendahnya kadar nib biji kakao. Menurut Mulato et al., (2004), kadar kulit ari yang memenuhi spesifikasi mutu biji kakao sebagai bahan baku produk cokelat adalah 12-13\%; dengan kadar nib yang dikehendaki tidak kurang dari 87-88\%.

Dari hasil penghitungan, kadar kulit ari biji kakao yang difermentasi sempurna adalah $12,10 \%$ dengan kadar nib 87,90\%. Sementara, kadar kulit ari biji kakao yang difermentasi tidak sempurna dan non fermentasi tidak sesuai dengan spesifikasi mutu, yaitu lebih dari 13\%; dengan kadar nib kurang dari 87\%. Semakin lama proses fermentasi, kadar kulit ari semakin berkurang; meskipun berdasarkan hasil analisis sidik ragam ternyata perlakuan tingkat fermentasi tidak berpengaruh nyata pada kadar kulit ari dan kadar nib (Tabel 1).

Nilai buah (pod value) menunjukkan jumlah buah yang diperlukan untuk mendapatkan $1 \mathrm{~kg}$ biji kakao kering. Menurut hasil penghitungan (Tabel 2) 22-24 buah kakao sudah dapat menghasilkan 1 kg biji kakao kering; sementara, menurut petani di Subak Abian Pucaksari, umumnya 1 kg biji kakao kering dapat dihasilkan dari 30 buah kakao. Perbedaan ini dapat terjadi karena nilai buah (pod value) tidak hanya ditentukan oleh jumlah dan bobot biji per buah, tetapi juga oleh keadaan biji dalam buah seperti biji sehat/tidak dan tingkat pengeringan biji. 
Tabel 2. Keragaan Kimia Biji Kakao Kering

\begin{tabular}{lccc}
\hline \multicolumn{1}{c}{ Parameter } & $\begin{array}{c}\text { Non } \\
\text { Fermentasi }\end{array}$ & $\begin{array}{c}\text { Fermentasi } \\
\text { Tidak Sempurna }\end{array}$ & $\begin{array}{c}\text { Fermentasi } \\
\text { Sempurna }\end{array}$ \\
\hline Kadar lemak (\%) & $22,43 \mathrm{a}$ & $24,74 \mathrm{~b}$ & $31,28 \mathrm{c}$ \\
Kadar air (\%) & $7,70 \mathrm{a}$ & $7,50 \mathrm{a}$ & $7,80 \mathrm{a}$ \\
pH & $6,35 \mathrm{c}$ & $5,50 \mathrm{~b}$ & $5,15 \mathrm{a}$ \\
Total asam (\%) & $0,94 \mathrm{a}$ & $1,46 \mathrm{~b}$ & $1,98 \mathrm{c}$ \\
Kadar gula pereduksi (\%) & $0,552 \mathrm{a}$ & $0,703 \mathrm{a}$ & $0,843 \mathrm{a}$ \\
\hline
\end{tabular}

Keterangan: Angka yang diikuti huruf yang sama pada lajur yang sama tidak berbeda nyata pada uji sidik ragam $(\alpha=$ $0,05)$

Tabel 2 menyajikan hasil analisis kimia biji kakao kering. Proses fermentasi dapat menurunkan kadar bahan bukan lemak melalui proses difusi lewat kulit, sehingga secara relatif kadar lemak akan meningkat (Yusianto, Winarno, \& Wahyuni, 1997). Dari hasil analisis mutu kimia, kadar lemak biji kakao yang difermentasi, baik sempurna maupun tidak sempurna lebih tinggi daripada biji non fermentasi, yaitu $24,74 \%-31,28 \%$ berbanding $22,43 \%$ dan secara analisis sidik ragam ketiganya berbeda nyata. Menurut Khomsan (2002), biji kakao umumnya mengandung lemak 31\%, karbohidrat $14 \%$, dan protein $9 \%$.

Menurut Winarno (1997), kestabilan optimum bahan pangan dapat tercapai pada kadar air 3$7 \%$, dimana bahan pangan menjadi tidak mudah terserang oleh mikroorganisme (bakteri dan jamur) serta tahan terhadap reaksi-reaksi kimia yang merusak bahan pangan, seperti oksidasi lemak. Proses fermentasi yang lebih lama dapat menyebabkan kadar air biji kakao kering yang dihasilkan lebih rendah. Selama proses fermentasi, komponen-komponen yang terdapat di dalam keping biji, termasuk juga air akan banyak berdifusi keluar, sehingga kandungan air di dalam keping biji akan menjadi berkurang. Dengan proses pengeringan, kadar air akan menjadi lebih rendah pula (Putra \& Wartini, 1998).

Dari hasil pengukuran pada Tabel 2, kadar air biji kakao kering masih berada di atas 7\%; oleh sebab itu, waktu penjemuran dapat diperpanjang sampai lebih dari 7 hari, sampai kadar air biji sama dengan atau kurang dari $7 \%$. Selain itu, penyimpanan biji kakao juga perlu diperhatikan, yaitu sebaiknya biji dikemas dalam wadah (karung) yang tertutup rapat dan disimpan dalam ruangan yang kering agar biji tidak menyerap uap air dan oksigen dari luar, yang dapat menyebabkan peningkatan kembali kadar air biji kakao.

Hasil pengukuran pH biji kakao berkisar 5,15-6,35. Semakin lama proses fermentasi, pH biji semakin menurun (Tabel 2). Menurut Dumadi (2000), pH biji kakao harus di atas 5,0 agar dapat memperbaiki citarasa khasnya. Biji kakao dengan $\mathrm{pH}$ relatif rendah dapat menghilangkan pembentukan calon aroma. Namun pH biji yang terlalu tinggi (lebih dari 6,0) juga perlu diwaspadai, karena dapat menyebabkan kerusakan aroma, yang ditandai dengan tumbuhnya bakteri aerofil yang dapat mendegradasi atau merusak asam amino.

Nilai $\mathrm{pH}$ berkorelasi negatif dengan nilai total asam, dimana semakin rendah $\mathrm{pH}$, total asam cenderung meningkat. Semakin lama proses fermentasi, nilai total asam semakin meningkat (Tabel 2). Nilai total asam pada akhir fermentasi yang masih dapat diterima oleh konsumen adalah 15 meq $\mathrm{NaOH} / 100$ gram. Keasaman biji yang lebih tinggi dapat menimbulkan cacat citarasa biji. Dari hasil analisis sidik ragam, tingkat fermentasi berpengaruh nyata pada nilai $\mathrm{pH}$ dan total asam biji kakao kering. 
Gula yang terdapat pada biji kakao sebelum fermentasi adalah sukrosa. Selama proses fermentasi, sukrosa diubah menjadi glukosa dan fruktosa (gula pereduksi) oleh enzim invertase di dalam kulit biji. Gula pereduksi berperan dalam proses pencokelatan biji serta pembentukan rasa dan aroma khas cokelat. Pada biji kakao yang tidak difermentasi atau difermentasi tidak sempurna akan mengandung lebih banyak sukrosa dan sedikit gula pereduksi. Dari hasil analisis pada Tabel 2 dapat dilihat bahwa biji kakao kering dengan perlakuan fermentasi sempurna memiliki kadar gula pereduksi yang lebih tinggi dibandingkan kedua perlakuan yang lain; meskipun dari hasil analisis sidik ragam, perlakuan tingkat fermentasi tidak berpengaruh nyata pada kadar gula pereduksi.

\section{Pasta Cokelat}

Kadar lemak pasta cokelat yang dibuat, baik dari biji fermentasi dan non fermentasi sangat tinggi, yaitu $52,77 \%-57,87 \% \mathrm{bb}$ (Tabel 3). Kadar lemak dan kadar air pasta berpengaruh pada rendemen lemak cokelat yang diperoleh, yaitu kadar lemak pasta minimal $40-45 \%$, kadar air $4 \%$, dengan ukuran partikel kurang dari 75 mm (Ditjen P2HP Deptan, 2006). Berdasarkan hasil analisis pada Tabel 3, dapat dikatakan bahwa kadar lemak dan kadar air pasta cokelat yang dihasilkan akan berpengaruh positif terhadap rendemen lemak cokelat yang diperoleh pada proses pengempaan.

Tabel 3. Analisis Mutu Kimia Pasta Cokelat

\begin{tabular}{|c|c|c|c|}
\hline Parameter & $\begin{array}{c}\text { Non } \\
\text { Fermentasi } \\
\end{array}$ & $\begin{array}{c}\text { Fermentasi } \\
\text { Tidak Sempurna }\end{array}$ & Fermentasi Sempurna \\
\hline Kadar lemak (\%) & $52,77 \mathrm{a}$ & $54,84 \mathrm{~b}$ & $57,87 \mathrm{c}$ \\
\hline Kadar air (\%) & $1,35 a$ & $3,19 \mathrm{c}$ & $1,57 b$ \\
\hline Kadar protein (\%) & $16,42 b$ & $15,86 b$ & $7,52 \mathrm{a}$ \\
\hline Kadar karbohidrat (\%) & $26,06 a b$ & $23,11 \mathrm{a}$ & $29,82 b$ \\
\hline Kadar abu (\%) & $3,40 \mathrm{a}$ & $3,00 \mathrm{a}$ & $3,22 \mathrm{a}$ \\
\hline
\end{tabular}

Keterangan : Angka yang diikuti huruf yang sama pada lajur yang sama tidak berbeda nyata pada uji sidik ragam $(a=0,05)$

Deskripsi panelis terhadap warna pasta cokelat adalah warna dominan pasta cokelat non fermentasi dan fermentasi tidak sempurna adalah cokelat gelap (70\% dan 60\%); sementara warna pasta cokelat dari biji fermentasi sempurna adalah cokelat bata (60\%) (Tabel 4). Bila dikaitkan dengan hasil uji rangking pada Tabel 5 , warna cokelat bata pada produk pasta lebih disukai daripada warna cokelat gelap. Hasil uji organoleptik pasta cokelat selengkapnya dapat dilihat pada Tabel 4 untuk uji deskriptif dan Tabel 5 untuk uji rangking.

Dari segi aroma, $100 \%$ panelis menilai aroma pasta dari biji fermentasi sempurna adalah khas cokelat. Hanya $60 \%$ panelis yang menilai pasta cokelat non fermentasi beraroma khas cokelat; dan bahkan hanya $30 \%$ untuk pasta dari biji fermentasi tidak sempurna. Aroma yang mendominasi pada pasta dari biji fermentasi tidak sempurna adalah langu (35\%), yaitu aroma seperti barang yang disimpan lama ('apek'). Kadar gula pereduksi dan pH biji kakao diduga berpengaruh terhadap aroma dan warna produk pasta yang didapatkan tersebut. 
Tabel 4. Analisis Mutu Organoleptik Pasta Cokelat (Uji Deskriptif)

\begin{tabular}{lccc}
\hline \multicolumn{1}{c}{ Atribut mutu } & $\begin{array}{c}\text { Non } \\
\text { Fermentasi (\%) }\end{array}$ & $\begin{array}{c}\text { Fermentasi } \\
\text { Tidak Sempurna (\%) }\end{array}$ & $\begin{array}{c}\text { Fermentasi } \\
\text { Sempurna (\%) }\end{array}$ \\
\hline Warna & & & 0 \\
\hline Cokelat gelap & 70 & 60 & 60 \\
Cokelat bata & 25 & 0 & 40 \\
Cokelat muda & 0 & 5 & 0 \\
Lain-lain & 5 & 35 & 100 \\
\hline Aroma & & & 0 \\
\hline Khas cokelat & 60 & 30 & 0 \\
Langu & 15 & 35 & 0 \\
Tidak ada aroma & 0 & 20 & 0 \\
Lain-lain & 25 & 15 & 70 \\
\hline Rasa pahit (bitterness) & & & 30 \\
\hline Pahit sekali & 65 & 5 & 0 \\
Pahit (khas cokelat) & 30 & 45 & 0 \\
Agak pahit & 5 & 50 & \\
Tidak terasa pahit & 0 & 0 & \\
Lain-lain & 0 & 0 & \\
\hline
\end{tabular}

Dari segi rasa pahit (bitterness), $70 \%$ panelis menilai rasa pahit pasta dari biji fermentasi sempurna adalah rasa pahit yang khas cokelat dan paling diminati (rangking 1) (Tabel 4). Sementara, mayoritas panelis $(65 \%)$ menilai pasta cokelat non fermentasi terasa pahit sekali; namun mereka lebih menyukainya dibandingkan pasta dari biji fermentasi tidak sempurna yang dinilai agak pahit (50\%). Khomsan (2002) menyebutkan bahwa rasa pahit sebenarnya merupakan rasa asli biji kakao yang disebabkan oleh adanya kandungan alkaloid; namun, setelah melalui beberapa proses, rasa pahit tersebut dapat diminimalkan sehingga dapat dihasilkan makanan cokelat yang mempunyai rasa yang disukai.

Tabel 5. Analisis Mutu Organoleptik Pasta Cokelat (Uji Rangking)

\begin{tabular}{|c|c|c|c|}
\hline Atribut mutu & $\begin{array}{c}\text { Non } \\
\text { Fermentasi }\end{array}$ & $\begin{array}{c}\text { Fermentasi } \\
\text { Tidak Sempurna }\end{array}$ & $\begin{array}{l}\text { Fermentasi } \\
\text { Sempurna }\end{array}$ \\
\hline Warna & 3 & 2 & 1 \\
\hline Aroma & 2 & 3 & 1 \\
\hline Rasa pahit (bitterness) & 2 & 3 & 1 \\
\hline
\end{tabular}

Secara keseluruhan, hasil uji rangking terhadap produk pasta cokelat menunjukkan bahwa panelis paling menyukai pasta dari biji fermentasi sempurna (Tabel 5). Menurut deskripsi panelis, pasta dari biji fermentasi sempurna berwarna cokelat bata $(60 \%)$, dengan aroma khas cokelat $(100 \%)$, dan rasa pahit khas cokelat $(70 \%)$ (Tabel 4$)$.

\section{Lemak Cokelat}

Hasil lemak cokelat yang diperoleh sangat dipengaruhi oleh kondisi pasta cokelat sebagai bahan baku kempa. Berdasarkan Tabel 3 mengenai hasil analisis kimia pasta cokelat, dimana kadar lemak pasta adalah sekitar $52-57 \%$ dan kadar air 1-3\%, didapatkan produk lemak cokelat dengan kandungan kimia seperti disajikan pada Tabel 6 . Meskipun kandungan lemak pada produk lemak 
cokelat sangat tinggi (97-99\%), namun lemak cokelat relatif tidak mudah tengik karena kadar air produk lemak cokelat yang sangat rendah, yaitu 0,05-0,13\%; dan juga adanya kandungan polifenol dalam cokelat $(6 \%)$ yang berfungsi sebagai antioksidan alami pencegah ketengikan (Khomsan, 2002).

Tabel 6. Analisis Mutu Kimia Lemak Cokelat

\begin{tabular}{lccc}
\hline \multicolumn{1}{c}{ Parameter } & $\begin{array}{c}\text { Non } \\
\text { Fermentasi }\end{array}$ & $\begin{array}{c}\text { Fermentasi } \\
\text { Tidak Sempurna }\end{array}$ & $\begin{array}{c}\text { Fermentasi } \\
\text { Sempurna }\end{array}$ \\
\hline Kadar lemak (\%) & $97,86 \mathrm{a}$ & $98,11 \mathrm{a}$ & $99,87 \mathrm{a}$ \\
Kadar air (\%) & $0,05 \mathrm{a}$ & $0,09 \mathrm{~b}$ & $0,13 \mathrm{c}$ \\
Kadar protein (\%) & $2,09 \mathrm{a}$ & $1,80 \mathrm{a}$ & $0,00 \mathrm{a}$ \\
Kadar karbohidrat (\%) & $0,00 \mathrm{a}$ & $0,00 \mathrm{a}$ & $0,00 \mathrm{a}$ \\
Kadar abu (\%) & $0,00 \mathrm{a}$ & $0,00 \mathrm{a}$ & $0,00 \mathrm{a}$ \\
\hline Ke & & &
\end{tabular}

Keterangan : Angka yang diikuti huruf yang sama pada lajur yang sama tidak berbeda nyata pada uji sidik ragam $(\alpha=$ $0,05)$

\section{Bubuk Cokelat}

Proses fermentasi dapat menurunkan kadar bahan bukan lemak, sehingga secara relatif kadar lemak akan meningkat (Yusianto et al. 1997). Hal ini juga tampak pada bubuk cokelat yang dibuat, dimana kadar lemak semakin meningkat dengan semakin lamanya waktu fermentasi. Hasil analisis mutu kimia bubuk cokelat selengkapnya dapat dilihat pada Tabel 7.

Hasil analisis kadar lemak dalam bubuk cokelat yang berkisar $27-37 \%$ bb masih relatif tinggi untuk standar bubuk cokelat, karena umumnya kadar lemak dalam bubuk cokelat berkisar 10-22\% (Mulato, Widyotomo, Misnawi, Sahali, \& Suharyanto, 2004). Kadar lemak bubuk cokelat yang masih relatif tinggi mungkin disebabkan oleh beberapa hal, seperti suhu kempa yang kurang dari $35{ }^{0} \mathrm{C}$ dan tekanan kempa yang kurang kuat (karena proses kempa dilakukan secara manual) sehingga lemak di dalam pasta pada saat dikempa tidak sepenuhnya terpisah dan masih terikat dalam bungkil cokelat. Kadar lemak yang terlalu tinggi pada bubuk cokelat akan berpengaruh pada karakteristik produk, seperti bubuk mudah menggumpal dan mudah lengket.

Tabel 7. Analisis Mutu Kimia Bubuk Cokelat

\begin{tabular}{lccc}
\hline \multicolumn{1}{c}{ Parameter } & $\begin{array}{c}\text { Non } \\
\text { Fermentasi }\end{array}$ & $\begin{array}{c}\text { Fermentasi } \\
\text { Tidak Sempurna }\end{array}$ & Fermentasi Sempurna \\
\hline Kadar lemak (\%) & $27,95 \mathrm{a}$ & $30,93 \mathrm{~b}$ & $37,78 \mathrm{c}$ \\
Kadar air (\%) & $7,94 \mathrm{~b}$ & $4,66 \mathrm{a}$ & $4,38 \mathrm{a}$ \\
Kadar protein (\%) & $19,57 \mathrm{~b}$ & $13,28 \mathrm{a}$ & $16,62 \mathrm{ab}$ \\
Kadar karbohidrat (\%) & $40,27 \mathrm{a}$ & $46,89 \mathrm{~b}$ & $36,62 \mathrm{a}$ \\
Kadar abu (\%) & $4,23 \mathrm{a}$ & $4,26 \mathrm{a}$ & $4,60 \mathrm{a}$ \\
pH & $6,30 \mathrm{c}$ & $5,85 \mathrm{~b}$ & $5,35 \mathrm{a}$ \\
\hline
\end{tabular}

Keterangan : Angka yang diikuti huruf yang sama pada lajur yang sama tidak berbeda nyata pada uji sidik ragam $(a=0,05)$

Kadar air yang dipersyaratkan untuk bubuk cokelat adalah maksimal 7\%bb. Kadar air bubuk cokelat yang didapatkan adalah sekitar 4\%bb untuk bubuk cokelat yang difermentasi; sementara untuk bubuk cokelat non fermentasi, kadar air masih di atas 7\%bb (Tabel 7) dan kemungkinan hal ini 
lebih disebabkan oleh kondisi penyimpanan yang kurang tepat sehingga produk menyerap uap air dari luar.

Hasil pengukuran $\mathrm{pH}$ menunjukkan bahwa $\mathrm{pH}$ bubuk cokelat yang dibuat dari biji yang difermentasi adalah 5,35-5,85; sementara pH bubuk cokelat non fermentasi adalah 6,30 (Tabel 7). Perbedaan nilai $\mathrm{pH}$ bubuk mengakibatkan perbedaan warna dan kegunaannya. Bubuk natural dengan $\mathrm{pH}$ antara 5,2-5,9 umumnya digunakan untuk industri roti; sementara bubuk alkalized (dutch) dengan $\mathrm{pH}$ di atas 6,0, bahkan sampai $\mathrm{pH}$ 8,1 umumnya digunakan untuk pembuatan minuman, puding, dan es krim (Biskuit halal, 2005). Perubahan warna bubuk cokelat akibat proses alkali adalah berkisar merah bata atau merah menjadi hitam sampai sangat hitam; atau dengan kata lain, bubuk cokelat dengan $\mathrm{pH}$ yang tinggi akan berwarna cenderung lebih gelap.

Hasil organoleptik (uji rangking dan uji deskriptif) produk bubuk cokelat seperti dapat dilihat pada Tabel 8 dan 9.

Tabel 8. Analisis Mutu Organoleptik Bubuk Cokelat (Uji Rangking)

\begin{tabular}{lccc}
\hline \multicolumn{1}{c}{ Atribut mutu } & $\begin{array}{c}\text { Non } \\
\text { Fermentasi }\end{array}$ & $\begin{array}{c}\text { Fermentasi Tidak } \\
\text { Sempurna }\end{array}$ & $\begin{array}{c}\text { Fermentasi } \\
\text { Sempurna }\end{array}$ \\
\hline Warna & 3 & 2 & 1 \\
Aroma & 3 & 2 & 1 \\
Rasa pahit (bitterness) & 3 & 2 & 1 \\
Tekstur & 2 & 3 & 1 \\
\hline
\end{tabular}

Tabel 9. Analisis Mutu Organoleptik Bubuk Cokelat (Uji Deskriptif)

\begin{tabular}{lccc}
\hline \multicolumn{1}{c}{ Atribut mutu } & $\begin{array}{c}\text { Non } \\
\text { Fermentasi (\%) }\end{array}$ & $\begin{array}{c}\text { Fermentasi } \\
\text { Tidak Sempurna (\%) }\end{array}$ & $\begin{array}{c}\text { Fermentasi Sempurna } \\
(\%)\end{array}$ \\
\hline Warna & & 0 & 25 \\
\hline Cokelat gelap & 50 & 40 & 55 \\
Cokelat bata & 10 & 60 & 15 \\
Cokelat muda & 10 & 0 & 5 \\
Lain-lain & 30 & & \\
\hline Aroma & & 50 & 60 \\
\hline Khas cokelat & 40 & 45 & 0 \\
Langu & 10 & 0 & 5 \\
Tidak ada aroma & 50 & 5 & 15 \\
Lain-lain & 10 & & 25 \\
\hline Rasa pahit (bitterness) & & 0 & 0 \\
\hline Pahit sekali & 20 & 45 & 0 \\
Pahit (khas cokelat) & 15 & 50 & 55 \\
Agak pahit & 55 & 5 & 40 \\
Tidak terasa pahit & 10 & 0 & 5 \\
Lain-lain & 0 & & 0 \\
\hline Tekstur & & 30 & \\
\hline Halus & 60 & 50 & \\
Agak halus & 35 & 20 & 0 \\
Tidak halus (kasar) & 5 & 0 & \\
Lain-lain & 0 & & \\
\hline
\end{tabular}


Secara keseluruhan, dari hasil uji rangking, panelis paling menyukai bubuk cokelat dari biji fermentasi sempurna, baik dari segi warna, aroma, rasa pahit (bitterness), dan tekstur (Tabel 8). Bila dikaitkan dengan hasil uji deskriptif (Tabel 9), penilaian panelis terhadap atribut mutu organoleptik bubuk dari biji fermentasi sempurna yang paling disukai adalah: $55 \%$ panelis menilai warna bubuk cokelat adalah cokelat bata, dengan aroma khas cokelat (60\%), dan rasa pahit yang khas cokelat $(60 \%)$, serta tekstur bubuk yang halus $(55 \%)$.

Sementara, menurut penilaian deskriptif panelis, bubuk dari biji fermentasi tidak sempurna yang secara umum menduduki rangking kedua cenderung berwarna cokelat muda (60\%), aroma khas cokelat $(50 \%)$ dan juga ada aroma langu seperti pada produk pastanya, yaitu sebanyak $45 \%$; rasa pahit kurang menonjol (50\%); dan secara tekstur, bubuk dari biji fermentasi tidak sempurna agak halus $(50 \%)$ (Tabel 9$)$.

\section{KESIMPULAN}

Proses fermentasi berpengaruh nyata terhadap mutu kimia biji kakao kering dan mutu kimia produk setengah jadi cokelat. Semakin lama proses fermentasi, kadar lemak biji kakao kering, pasta, lemak, dan bubuk cokelat semakin meningkat. Proses fermentasi tidak berpengaruh nyata terhadap mutu fisik biji kakao kering. Secara umum, keragaan mutu fisik ketiga biji kakao kering yang dihasilkan baik dan termasuk dalam kelompok biji Mutu A. Secara keseluruhan, panelis memberikan rangking tertinggi untuk atribut mutu organoleptik pasta dan bubuk cokelat dari biji yang difermentasi sempurna.

\section{REFERENSI}

Atmawinata, O., Mulato, S., Widyotomo, S., \& Yusianto. (1998). Teknik pra pengolahan biji kakao segar secara mekanis untuk mempersingkat waktu fermentasi dan menurunkan kemasaman biji. Pelita Perkebunan, Jurnal Penelitian Kopi dan Kakao, 14(1), April 1998.

Ditjen P2HP Deptan. (2006). SOP produk olahan kakao. Diambil tanggal 7 September 2006, dari http://agribisnis. deptan.go.id.

Dumadi, S. R. (2000). Hubungan penyimpanan buah kakao dengan perubahan gula dan pengasaman biji selama proses fermentasi. Jurnal Sains dan Teknologi Indonesia, 2 (3); 3339.

Khomsan, A. (2002). Cokelat baik untuk jantung dan suasana hati. Diambil tanggal 7 September 2006, dari http://kolom.pacific.net.id/ind.

Misnawi. (2005). Peranan pengolahan terhadap pembentukan citarasa cokelat. Warta Pusat Penelitian Kopi dan Kakao, 21 (3). Oktober 2005, Jember.

Mulato, S., Widyotomo, S., \& Handaka. (2004). Disain teknologi pengolahan pasta, lemak, dan bubuk cokelat untuk kelompok tani. Warta Penelitian dan Pengembangan Pertanian, Badan Litbang Pertanian, Departemen Pertanian. Diambil pada 7 September 2006, dari http://pustaka.bogor.net.

Mulato, S., Widyotomo, S., Misnawi, S., \& Suharyanto, E. (2004). Petunjuk teknis pengolahan produk primer dan sekunder kakao. Jakarta: Bagian Proyek Penelitian dan Pengembangan Kopi dan Kakao, Pusat Penelitian Kopi dan Kakao Indonesia.

[Pemprov] Pemerintah Provinsi Bali. (2004). Data Bali membangun 2004. Denpasar: Badan Perencanaan Pembangunan Daerah. 
Putra, G. P. G., \& Wartini, M. (1998). Penambahan asam asetat sebelum fermentasi sebagai upaya mempersingkat waktu fermentasi dengan kualitas hasil biji kakao kering siap ekspor. Laporan Akhir Hasil Penelitian Dosen Muda. Denpasar: Program Studi Teknologi Pertanian, Universitas Udayana.

Biskuit halal banyak ragamnya. (2005, Januari 20) Republika. Diambil pada 1 April 2005.

Widyotomo, S., Mulato, S., \& Handaka. (2004). Mengenal lebih dalam teknologi pengolahan biji kakao. Warta Penelitian dan Pengembangan Pertanian, 26 (2).

Winarno, F. G. (1997). Kimia pangan dan gizi. Jakarta: PT. Gramedia Pustaka Utama.

Yusianto. (1994). Beberapa metode fermentasi biji kakao skala kecil. Warta Pusat Penelitian Kopi dan Kakao, 18, 11-17.

Yusianto, H., Winarno, \& Wahyuni T. (1997). Mutu dan pola citarasa beberapa klon kakao lindak. Pelita Perkebunan, 13 (3), 171-187. 